\title{
Waldemar Jaskulski
}

Lubraniec

\section{Działalność wojsk koalicyjnych w rejonie Zatoki Perskiej w latach 1990-1991 (aspekty polityczne i militarne)}

Korzenie irackich roszczeń wobec Kuwejtu sięgają końca XIX w. Wówczas to małe państewko wchodziło w skład imperium osmańskiego, stanowiąc jednocześnie brytyjski protektorat. Po upadku imperium osmańskiego, Irak uważał się za spadkobiercę Kuwejtu pozostającego nadal w sferze wpływów brytyjskich ${ }^{1}$. W połowie 1932 r. tuż przed uzyskaniem suwerenności, pod presją Brytyjczyków, władze irackie uznały granicę z Kuwejtem, która miała przebiegać według ustaleń brytyjsko-osmańskich z 1913 r. Przypomnę, że granica ta pozostawiała po stronie Kuwejtu m.in. wyspy Bubijan oraz Warbę położoną naprzeciw irackiego portu Umm Kasr². W 1951 r. toczyły się rozmowy iracko-kuwejckich w sprawie demarkacji granicy. Wówczas Irakijczycy zażądali wyspy Warba, co doprowadziło do zerwania negocjacji. Kilka lat później Bagdad ponowił żądanie, domagając się przy tym części wybrzeża kuwejckiego położonego na południe od Umm Kasr. I tym razem pod wpływem Brytyjczyków zachowano status quo. Żądania Iraku wobec Kuwejtu wzmogły się, gdy w połowie lipca 1958 r. obalono posłusznego Brytyjczykom króla Fajsala, a władzę przejęli rewolucyjni republikanie z gen. Abdelem Karimem Kassem na czele 3 . Wkrótce po uzyskaniu przez Kuwejt suwerenności (19 VI 1961 r.) przywódca Iraku stwierdził, że uważa go za integralną część swojego państwa. W odpowiedzi władze Kuwejtu zwróciły się o pomoc do Wielkiej Brytanii, co zaowocowało kontyngentem 6000 żołnierzy ${ }^{4}$. W lipcu 1961 r. Kuwejt został przyjęty do Ligi Państw Arabskich, a w maju 1963 r. do Organizacji Narodów Zjednoczonych (ONZ).

1 Na mocy porozumienia brytyjsko-osmańskiego z 1913 r. Kuwejt należał do prowincji Basra. Na mocy traktatów w Sèvres (1920) i Lozannie (1923) Basra znalazła się na terytorium Iraku. Stąd też, zdaniem Bagdadu, do Iraku powinien zostać włączony także Kuwejt. Vide S. B. Samaan, A. H. Muhareb, An Aggression on the Mind. A War Gives Birth to Another, Kuwait 1995, s. 61-62; M. Nouschi, Maty atlas XX wieku, Warszawa 2006, s. 55-56.

2 W. Szymborski, Zatoka Perska, Bydgoszcz 1999, s. 112.

3 J. Stefański, Geneza i przebieg wojny w Zatoce Perskiej, „Żołnierz Polski” z 21 IV 1991, nr 16, s. 4.

4 W wyniku nacisku Iraku wojska te zostały zastąpione przez siły międzyarabskie. 
W lutym 1963 r. obalono dotychczasowy rząd, co przyczyniło się od ocieplenia stosunków iracko-kuwejckich ${ }^{5}$. Do zaostrzenia stosunków doszło w marcu 1973 r., kiedy tu oddziały irackie zajęły niewielką powierzchnię Kuwejtu. Wówczas to Bagdad upomniał się o pas kuwejckiego wybrzeża oraz zażądał wydzierżawienia wysp Warba i Bubijan. Ponadto Irakijczycy wystąpili z projektem budowy eksterytorialnego portu w stolicy Kuwejtu. Kuwejt odrzucił wszystkie te żądania. Tym razem do negocjacji doprowadził przewodniczący Organizacji Wyzwolenia Palestyny Jaser Arafat.

W czasie wojny iracko-irańskiej (1980-1988)6 ${ }^{6}$, Irak kierowany przez Saddama Husajna ${ }^{7}$ spełniał rolę tarczy powstrzymującej rozlew rewolucji islamskiej ${ }^{8}$. Wsparcie uzyskał od Stanów Zjednoczonych oraz państw arabskich m.in. Kuwejtu, który pożyczył mu 10-12 miliardów dolarów9 . Po zakończeniu wojny, iracki dyktator zażądał m.in. od Kuwejtu umorzenia zaciągniętych długów. W marcu 1990 r. wystąpił o dalsze pożyczki na odbudowę zniszczonego wojną państwa ${ }^{10}$. Środki te miały dostarczyć monarchie położone w rejonie Zatoki Perskiej, m.in. Arabia Saudyjska oraz Kuwejt. W przypadku odmowy, groził użyciem siły. Jednocześnie dla zapewnienia sobie poparcia państw arabskich wzniecił kampanię przeciw USA i Izraelowi.

W połowie lipca 1990 r. Irak oskarżył m.in. Kuwejt o przekroczenie limitów wydobycia ropy, co przyczyniło się do spadku ceny tego surowca ${ }^{11}$. Władze

5 M.in. z Kuwejtu wycofano siły międzyarabskie.

6 W. Michnik, Dtuga droga do wojny - USA i przyczyny II wojny w Zatoce Perskiej, [w:] Irak. Dylematy amerykańskiej interwencji, red. W. Dzielski, W. Michnik, Kraków 2007, s. 104.

7 Po przeprowadzonym w 1968 r. zamachu stanu przez partię BAAS (Socjalistyczna Partia Odrodzenia Iraku), Saddam Husajn został mianowany zastępcą gen. Ahmeda Hassana al - Bakra, wówczas przewodniczącego najwyższego organu irackiego, jakim była Rady Dowództwa Rewolucji. Niemal przez 10 lat był drugą, co do ważności osobą w państwie. Władzę objął w lipcu 1979 r. Vide R. Bielecki, Pustynna Burza, Warszawa 1991, s. 10-20; H. M. Królikowski, Cz. Marcinkowski, Irak 2003, Warszawa 2003, s. 15; W. Dzielski, Idealizm George'a W. Busha a II wojna w Zatoce Perskiej, [w:] Irak. Dylematy amerykańskiej interwencji, red. W. Dzielski, W. Michnik, Kraków 2007, s. 72-76; S. Tanner, Wojny Bushów. Ojciec i syn jako zwierzchnicy sit zbrojnych, Wrocław 2007, s. 63-74; A. Łomanowski, Portret dyktatora, „Gazeta Wyborcza” z 21 VIII 1990, nr 193, s. 6.

8 J. Modrzejewska-Leśniewska, Walka o hegemonię w rejonie Zatoki Perskiej. Wojna iracko-irańska 1980-1988, [w:] Zarys dziejów Afryki i Azji 1869-1996. Historia konfliktów, red. A. Bartnicki, Warszawa 1996, s. 438-450; B. Rubin, Reshaping The Middle East, Foreign Affairs, Summer, New York 1990, s. 134-135.

9 W. Szymborski, op. cit., s. 117; R. Bielecki, op. cit., s. 27. Autor podał kwotę 30 mld dolarów; Także, J. Haschka, Wojna iracko-kuwejcka. (Robert Bielecki: Pustynna burza, Warszawa 1991) artykuł recenzyjny, „Myśl Wojskowa” Warszawa 1991, nr 4, s. 154.

10 J. Miller, L. Mylroie, Saddam Husajn. Wojna w Zatoce, Warszawa 1991, s. 18-22.

11 Irak domagał się podniesienia ceny ropy do 25 dolarów za baryłkę, podczas gdy kraje arabskie sprzedawały baryłkę za 21 dolarów. W. Szymborski, op. cit., s. 121. Nieco inny stosunek cen podał R. Bielecki, (op. cit., s. 28). Vide też E. L. Morse, The coming Oil Revolution, Foreign Affairs, Winter, New York 1990/91, s. 41. 
Kuwejtu zostały posądzone o pompowanie ,irackiej” ropy ze złoża Rumailah, znajdującego się po obu stronach granicy. Wobec tego Husajn zażądał 2,4 mld dolarów odszkodowania ${ }^{12}$. Ponadto Bagdad domagał się przesunięcia granicy o $4 \mathrm{~km}$ na korzyść Iraku, wydzierżawienia wysp Warba i Bubijan oraz przyznania nowych pożyczek ${ }^{13}$. Narastający konflikt próbowali zażegnać prezydent Egiptu Hosni Mubarak i król Jordanii Husajn ${ }^{14}$, doprowadzając 31 lipca w Dżiddzie (Jeddah) do rozmów iracko-kuwejckich. Wobec nieustępliwości strony irackiej, jeszcze tego samego dnia negocjacje zostały zerwane ${ }^{15}$.

Jeszcze przed rozpoczęciem rokowań, 26 lipca 1990 r. oddziały irackiej Gwardii Republikańskiej w sile 30000 zbliżyły się do 320 km linii demarkacyjnej z Kuwejtem. W następnych dniach lipca ich liczba wzrosła do $100000^{16}$. W nocy z 2 na 3 sierpnia trzy zgrupowania wojsk irackich zaatakowały Kuwejt ${ }^{17}$. Wojska kuwejckie wspierane przez samoloty Mirage F1 i A-4KU stawiały opór prawie trzy dni, po czym zostały wycofane do Arabii Saudyjskiej ${ }^{18}$. Agresja ta była pierwszym przypadkiem od 1945 r., kiedy jedno państwo doprowadziło do fizycznej likwidacji drugiego państwa. Rada Dowództwa Rewolucji 8 sierpnia anektowała Kuwejt ${ }^{19}$, a 28 sierpnia Husajn ogłosił go 19 prowincją Iraku ${ }^{20}$. Po zajęciu Kuwejtu Irakijczycy przystąpili do łamania oporu, dopuszczając się przy tym zbrodni wojennych ${ }^{21}$. Zakładników z państw zachodnich rozmieszczono w obiektach strategicznych jako, „żywe tarcze”22. Już w czasie nalotów alianckich

12 „Newsweek” z 6 VIII 1990, nr 32, s. 31.

13 S. B. Samaan, A. H. Muhareb, op. cit., s. 24-53.

14 Szerzej o stosunkach Jordanii z Irakiem pisali m.in.: S. Reed, Jordan and The Gulf Crisis, Foreign Affairs, Winter, New York 1990/91, s. 21 i n.

15 P. Salinger, E. Laurent, Konflikt w Zatoce Perskiej. Taje dokumenty, Kraków 1991, s. 65-69.

16 Ibidem, s. 61-63.

17 S. B. Samaan, A. H. Muhareb, op. cit., s. 112; Iracki napad na Kuwejt, „Gazeta Wyborcza” z 3 VIII 1990, nr 179, s. 1, 4; K. S., Wojna na pustyni. Irackie czotgi w Kuwejcie, „Trybuna” z 3 III 1991, nr 44, s. 1; F. Ajami, The Summer of Arab Discontent, Foreign Affairs, Winter, New York 1990/91, s. 1-2.

18 W. Pawłowski, Wojna o baryłki, „Polityka” z 11 VIII 1990, nr 32, s. 1, 12.

19 Kuwejt anektowany, „Gazeta Wyborcza” z 6 VIII 1990, nr 181, s. 1.

20 A. Ł., Kalendarium Konfliktu nad Zatoka Perska, „Wojskowy Przegląd Zagraniczny” Warszawa 1991, nr 1, s. 94, 97; Chronologia wydarzeń, „Życie Warszawy” z 19-20 I 1991, nr 16, s. 5; R. Bielecki, op. cit., s. 33; K. Nowak, Wojna w Zatoce Perskiej, „WPH” Warszawa 1992, nr 1, s. 6.

21 Vide The Iraqi War Criminals and Their Crimes During the Iraqi Occupation of Kuwait, Kuwait 1998, s. 27 i n.

22 W XII 1990 r. zakładnicy - cudzoziemcy zostali uwolnieni. Do osłony, przed atakiem lotnictwa koalicji Husajn użył ludności cywilnej. Vide Kilkuset zabitych w bunkrze, „Życie Warszawy” z 14 II 1991, nr 38, s. 5; T. T. S., Masakra w Bagdadzie, „Rzeczpospolita” z 15 II 1991, nr 39, s. 1; S. Grzymski, Wojna coraz brutalniejsza, „Rzeczpospolita” z 15 II 1991, nr 39, s. 1, 7; Protesty po nalocie na schron w Bagdadzie, ,Życie Warszawy” z 15 II 1991, nr 39, s. 1, 6. 
Irakijczycy podpalili szyby naftowe ${ }^{23}$ oraz wypuścili do Zatoki Perskiej ponad 10 mln baryłek ropy ${ }^{24}$. Działaniom tym towarzyszyła propaganda wzywająca do opuszczenia przez Izrael terytoriów okupowanych, utworzenia państwa Palestyńskiego oraz likwidacji obcych wojsk w rejonie Zatoki Perskiej. Wszystko to miało odciągnąć państwa arabskie od koalicji.

Wojska irackie skoncentrowane w Kuwejcie i w południowym Iraku liczyły około 540000 żołnierzy. Na tym obszarze rozlokowano siedem dywizji pancernych, pięć dywizji zmechanizowanych oraz dwadzieścia dwie dywizje piechoty. Na północno-wschodnim odcinku granicy iracko-kuwejckiej jako odwód operacyjny rozmieszczono lepiej wyposażone dywizje elitarnej Gwardii Republikańskiej. W jej skład weszły: 1. Dywizja Pancerna „Hammurabi”, 2. Dywizja Pancerna „Medina”, 2. Dywizja Zmechanizowana „Tawakalna”, 4. Dywizja Zmechanizowana „Al-Faw”, 5. Dywizja Zmechanizowana „Bagdad”, 6. Dywizja Zmechanizowana „Nabuchodonozor”, 7. Dywizja Zmechanizowana „Adnan” oraz Dywizja Sił Specjalnych ${ }^{25}$. Ponadto w tym rejonie operowało kilkanaście samodzielnych brygad ${ }^{26}$. Na ich uzbrojeniu znalazło się 4280 czołgów (głównie radzieckie T-72, T-62, T-59/69, T-54), 2800 bojowych wozów piechoty i transporterów opancerzonych oraz 3100 dział. Na uwagę zasługują haubice G-5 kal. $155 \mathrm{~mm}$, którym nie dorównywały haubice amerykańskie ${ }^{27}$. Według obowiązującej doktryny główny ciężar walk wziąć miały na siebie wojska lądowe. Pancerne odwody i ogień ciężkiej artylerii miały wystarczyć do powstrzymania przeciwnika, który przedarł się przez pierwszą linię piechoty ${ }^{28}$. Po rozpoczę-

23 S. Grzymski, W drodze do wyzwolonego państwa, ,Rzeczpospolita” z 5 III 1991, nr 54, s. 1, 7.

24 S. G., Szaleństwo i desperacja Husajna. Wyciek ropy zatrzymany - skutki pozostały, „Rzeczpospolita” z 29 I 1991, nr 24, s. 1; „Newsweek” z 4 II 1991, nr 5, s. 22-24.

25 J. Biziewski, Pustynna Burza, cz. 2, Warszawa 1994, s. 47. Vide też Idem, Pustynna Burza, cz. 1, s. 13. Około piętnastu dywizji Irakijczycy rozmieścili na granicy z Turcją, Syrią i Iranem. Dwie dywizje na Półwyspie Al-Few wiązała flota stacjonująca w Zatoce Perskiej. Flota ta wiązała, także cztery dywizje broniące wybrzeża Kuwejtu.

26 J. Biziewski, op. cit., cz. 1, Warszawa 1994, s. 13. Autor podał, że związki te wchodziły w skład czterech korpusów armijnych: II., III., IV., VII. oraz dwóch korpusów gwardii. Ponoć nie było korpusów w strukturach armii irackiej.

27 K. Nowak, op. cit., s. 9. Vide też P. A. Szudek, Wojna nad Zatoka Perska, „Orzeł Biały” Londyn 1991, nr 1462, s. 5-8; B. Hynowski, J. Markowski, Technika nad Zatokq Perskq, cz. 2, „Wojskowy Przegląd Techniczny” Warszawa 1991, nr 3, s. 23-25.

28 S. Sawin, Inżynieryjne zabezpieczenie działań bojowych koalicji antyirackiej $w$ rejonie Z. Perskiej, „Wojskowy Przegląd Zagraniczny” Warszawa 1992, nr 3, s. 122-126. Pomimo intensywnego bombardowania przez lotnictwo koalicji, 30 I $1991 \mathrm{r}$. Irakijczycy zdołali wedrzeć się na terytorium Arabii Saudyjskiej i na krótko opanować przygraniczne miasto Khafji. Vide T. T. S., Pierwsza bitwa ladowa, „Rzeczpospolita” z 1 II 1991, nr 27, s. 1; Irak szykuje szturm pancerny, „Życie Warszawy” z 2-3 II 1991, nr 28, s. 1, 5; „Newsweek” z 11 II 1991, nr 6, s. 11-12; J. Rajch, Wojna z powietrza schodzi na ląd, „Polska Zbrojna” z 9 I 1991, nr 6, s. 1-2; R. Bielecki, op. cit., s. $100-105$. 
ciu ofensywy lądowej, w wyniku przewagi Sprzymierzonych oraz działań grup psychologicznych ${ }^{29}$ wiele pododdziałów poddało się ${ }^{30}$.

Wsparcie z powietrza wojskom lądowym miało zapewnić około 570 samolotów typu: MiG-21, MiG-23, MiG-25, MiG-2931, Su-20/22, Su-24, Mirage F1 oraz 160 śmigłowców bojowych. Podkreślić trzeba, że dowództwo irackie zbagatelizowano (podobnie jak w wojnie $\mathrm{z}$ Iranem) rolę lotnictwa ze względu, jak sądzono, na jego małą skuteczność. Uważano, że lotnictwo powinno wejść do działań w ostateczności ${ }^{32}$.

Irakijczycy nie posiadali nowoczesnych systemów rozpoznania, z tego powodu byli pozbawieni informacji o dyslokacji wojsk przeciwnika ${ }^{33}$. Także niewielką wartość bojową przedstawiała licząca około 5000 ludzi flota iracka ${ }^{34}$. Natomiast Husajn ostrzegał przed użyciem broni chemicznej ${ }^{35}$.

${ }^{29}$ H. Porajski, Działania psychologiczne nad Zatoka Perska, „Przegląd Wojsk Lądowych” Warszawa 1992, nr 2, s. 95-98.

30 Zdaniem rzecznika sił sojuszniczych gen. Richarda Neala w pierwszych dniach działań lądowych największq dotychczas trudność sprawiaja masowo poddajacy się żotnierze iraccy. S. Grzymowski, Śmiertelne trafienia w al-Chobar, „Rzeczpospolita” z 27 II 1991, nr 49, s. 1. Vide też J. Klabiński, 500 jeńców na godzinę, „Gazeta Wyborcza” z 25 II 1991, nr 47, s. 5; K. G., Kuwejt w dymie i ogniu, „Rzeczpospolita” z 26 II 1991, nr 48, s. 1; Los jeńca, „Gazeta Wyborcza”, nr 48 z 26 II 1991 r., s. 5; S. Grzymowski, Jeńcy padli na kolana, „Rzeczpospolita” z 28 II 1991, nr 50, s. 1,9 .

31 T. Pieciukiewicz, F-16 Fight Falcon i MiG-29 - podobno sq podobne, „Przegląd Wojsk Lotniczych i Obrony Powietrznej” Warszawa 1991, nr 9, s. 54-63.

32 T. Pieciukiewicz, Lotnictwo Iraku - kolos na glinianych nogach, „Przegląd Wojsk Lotniczych i Obrony Powietrznej" Warszawa 1991, nr 7-8, s. 82-87; Idem, Lotnictwo Iraku - kolos na glinianych nogach, „Technika Wojskowa” Warszawa 1991, nr 5, s. 8-9; J. Markowski, B. Hynowski, Technika nad Zatoka Perska, „Wojskowy Przegląd Techniczny” Warszawa 1991, nr 2, s. 23-32. S. Grzymski, Czekają na rozkaz, „Rzeczpospolita” z 17 I 1991, nr 14, s. 5. Warto dodać, że około 150 maszyn irackich zostało wyprowadzonych do Iranu i Sudanu, gdzie ich załogi internowano. K. G., Dezercja czy rozkaz, „Rzeczpospolita” z 30 I 1991, nr 25, s. 1.

33 B. Balcerowicz, Wojna w Zatoce Perskiej - przyczyny i skutki, „Myśl Wojskowa” Warszawa 1991, nr 5, s. 177; Zatoka Perska. Siły Zbrojne stron konfliktu, „Technika Wojskowa” 1991, nr 1, s. 1.

34 Charakterystyki armii Husajna dokonał gen. Hassan Namib. Vide Rywal Husajna o sytuacji w Iraki, „Życie Warszawy” z 8 II 1991, nr 33, s. 6, Vide też K. Piątkowski, Wojna w Zatoce próba podsumowania, „Technika Wojskowa” Warszawa 1991, nr 5, s. 2-4.

35 L. Szczerba, Gdyby doszło do wojny w Zatoce Perskiej (Rozmowy z ekspertami), „Polska Zbrojna” z 10 I 1991, nr 7, s. 1; J. Rajch, Kiedy Husajn użyje broni chemicznej?, „Polska Zbrojna” z 6 II 1991, nr 26, s. 1; Idem, Ginq ludzie rosna straty, „Polska Zbrojna” z 11 I 1991, nr 29, s. 1-2. Vide Hearings before the Subcommittee on Human Resources and Intergovernmental Relations of the Committee on Government Reform and Oversight Mouse of Representatives One Hundred Fourth Congress Second Session March 11, 28; June 25; and September 19, 1996, Washington 1997, s. 390-391. 
Obronę iracką rozciągnięto wzdłuż granicy iracko-saudyjskiej i kuwejcko-saudyjskiej. Natomiast główny wysiłek zamierzano skupić na obronie miasta Kuwejt i Basry. Dowództwo irackie spodziewało się ataku od strony Zatoki Perskiej i z południa. Stąd też rozbudowano mocnienia od wybrzeża do Wadi al Batin. Wybrzeża miał bronić pas umocnień, pola minowe oraz zasieki z drutu kolczastego. Ponadto Irakijczycy dysponowali pociskami Exocet i pociskami ziemia - woda Silkworm, którymi można było ostrzelać cele nawodne ${ }^{36}$.

$\mathrm{Na}$ uzbrojeniu armii irackiej znalazły się zakupione od ZSRR rakiety taktyczne $\mathrm{Scud}^{37}$. Po wojnie z Iranem przystąpiono do ich przeróbek zwiększając zasięg do $625 \mathrm{~km}$ w Al Hussein ${ }^{38}$ i do 870 km w Al Abbas ${ }^{39} .18$ stycznia $1991 \mathrm{r}$. na Izrael spadł pierwszy z 48 Scudów $^{40}$. Wciągnięcie Izraela do wojny, zdaniem irackiego dyktatora, miało przyczynić się do rozpadu koalicji ${ }^{41}$. Irakijczycy wystrzelili ponad 90 tych rakiet ${ }^{42}$, kierując je na Dhahran ${ }^{43}$, Hajfę ${ }^{44}$ Tel Awiw ${ }^{45}$,

36 R. Sławiński, Irak pokonany, „Przegląd Wojsk Lotniczych i Obrony Powietrznej” Warszawa 1991, nr 6, s. 83-88.

37 Miały one zasięg do $300 \mathrm{~km}$ i mogły przenosić $1000 \mathrm{~kg}$ głowice jądrowe, konwencjonalne oraz chemiczne. Odpalane były zarówno z wyrzutni stacjonarnych, jak i ruchomych. Vide S. Nowodworski, O potomstwie broni „V”, „Orzeł Biały”, Londyn 1991, nr 1462, s. 10-11; J. Wojciechowski, Rakiety taktyczne „Scud”, „Technika Wojskowa” Warszawa 1991, nr 4, s. 10-11.

38 K. Leski, Al - Husajn nie umywa sie do Al-Hijara, „Gazeta Wyborcza” z 19 II 1991, nr 42, s. 5.

39 Były to ich irackie nazwy. W nomenklaturze międzynarodowej używano nazwy Scud.

40 K. Gebert, Wojna czterdziestoletnia, Warszawa 2004, s. 158.

41 T. Wróblewski, Przygotowania do wojny nad Zatoka, „Życie Warszawy” z 8 I 1991, nr 6, s. 1, 5; E. Boniecka, rakiety nie wyręczq polityków, „Życie Warszawy” z 19-20 I 1991, nr 16, s. 5; K. Kołodziejczyk, Nowa faza, „Rzeczpospolita” z 21 I 1991, nr 17, s. 1; R.M., Jaka będzie odpowiedź Izraela, „Rzeczpospolita” z 21 I 1991, nr 17, s. 1; P. Kłudka, „Pustynna Burza”, „Wojsko i Wychowanie” Warszawa 1991, nr 5, s. 82-83.

42 P. Durys, P. Pacholski, Broń masowego rażenia Iraku. Ocena i ewolucja zagrożenia, Toruń 2002, s. 14.

43 Na froncie bez zmian, „Polska Zbrojna” z 25-27 I 1991, nr 18, s. 1-2.

44 Czy będzie kontratak, „Gazeta Wyborcza” z 19-20 VIII 1990, nr 16, s. 1; K. Leski, Syreny zawyły o drugiej w nocy, „Gazeta Wyborcza” z 19-20 VIII 1990, nr 16, s. 6.

45 S. G., Eksplozja rakiety $w$ Tel Awiwie, „Rzeczpospolita” z 24 I 1991, nr 20, s. 1; S. G., „Pustynna burza” i rakiety, „Rzeczpospolita” z 25 I 1991, nr 21, s. 1; K. Leski, Znów atak na Izrael, „Gazeta Wyborcza” z 26-27 VIII 1990, nr 22, s. 1; A. Klugman, Życie w napięciu, „Rzeczpospolita” z 28 I 1991, nr 23, s. 9; Idem, Gdy sufit dotyka podtogi..., „Rzeczpospolita” z 29 I 1991, nr 24, s. 1; Idem, Iracka rakieta ostudziła entuzjazm Palestyńczyków, „Rzeczpospolita” z 31 I 1991, nr 26, s. 7; K. G., Alianci nie gotowi do walk ladowych, „Rzeczpospolita” z 2-3 II 1991, nr 248, s. 1; A. Klugman, 11. atak rakietowy, „Rzeczpospolita” z 5 II 1991, nr 29, s. 7; Idem, „Izraelska szklanka wody”, M. W., Broń dla Iraku, „Rzeczpospolita” z 12 II 1991, nr 36, s. 7; A. Klugman, Rośnie zagrożenie bronia „C”, „Rzeczpospolita” z 22 II 1991, nr 45, s. 9; Idem, Izrael przygotowany na wszystko, „Rzeczpospolita” z 26 II 1991, nr 48, s. 7; Idem, Dwie rakiety na Izrael, „Rzeczpospolita” z 27 II 1991, nr 49, s. 1, 9. 
Rijad $^{46}$ oraz al-Chobar ${ }^{47}$. Do zwalczania ich koalicja i Izrael używali rakiet Patriot $^{48}$, które dawały blisko $90 \%$ skuteczność ${ }^{49}$.

Inwazja Iraku na Kuwejt spotkała się z natychmiastowym potępieniem przez Radę Bezpieczeństwa ONZ. W dniu inwazji organ ten wydał pierwszą z dwunastu rezolucji wprowadzających bardzo ostre sankcje przeciwko agresorowi. Rezolucja nr 660 wzywała Husajna do natychmiastowego opuszczenia Kuwejtu. 6 sierpnia uchwalono kolejną rezolucję (661) wprowadzająca embargo na eksport i import z i do Iraku i Kuwejtu aż do wycofania wojsk okupacyjnych ${ }^{50}$. Wobec braku reakcji ze strony prezydenta Iraku 29 listopada uchwalono rezolucję nr 678 . Zezwalała ona na użycie „wszystkich niezbędnych środków”" ${ }^{1}$ potrzebnych do wyzwolenia Kuwejtu, jeżeli do 15 stycznia 1991 r. wojska irackie nie zostaną wycofane, a wszyscy zakładnicy uwolnieni ${ }^{52}$. Działania przeciwko Husajnowi poparł także ZSRR, tracący wtenczas pozycję światowego mocarstwa ${ }^{53}$. Państwo to

46 „Życie Warszawy” z 29 I 1991, nr 24, s. 1; S. Grzymski, Wojna będzie dtuga, „Rzeczpospolita” z 22 I 1991, nr 18, s. 1; K. G., „Patriot” trafia, „Rzeczpospolita” z 23 I 1991, nr 19, s. 1; K. G., Dezercja czy rozkaz, „Rzeczpospolita” z 30 I 1991, nr 25, s. 1; J. Rajch, Husajn: Użyjemy każdej broni, „Życie Warszawy” z 4 II 1991, nr 29, s. 1, 5; T. Wróblewski, Husajn montuje głowice chemiczne, „Życie Warszawy” z 6 II 1991, nr 31, s. 1, 5.

47 Alianci na przedmieściach stolicy Kuwejtu, ,Życie Warszawy, nr 47 z 25 II 1991 r., s. 5; Irak odda Kuwejt?, „Gazeta Wyborcza” z 26 II 1991, nr 48, s. 1; S. Grzymski, Śmiertelne trafienie $w$ al Chobar, „Rzeczpospolita” z 27 II 1991, nr 49, s. 1, 9; Idem, Jeńcy padli na kolana, „Rzeczpospolita” z 28 II 1991, nr 50, s. 1, 9.

48 A. Klugman, Amerykański most powietrzny z rakietami „Patriot”, „Rzeczpospolita” z 21 I 1991, nr 17, s. 9; D. Otto, Pojedynek, „Żołnierz Polski” z 3 II 1991, nr 5, s. 4; T. Vieweger, „Patriot” poluje na „Scuda”, „Wiraże” z 3 II 1991, nr 3, s. 5; G. Czapraka, Kompleks op Patriot, „Przegląd Wojsk Lotniczych i Obrony Powietrznej” Warszawa 1991, nr 5, s. 86-88; P. Gallois, Rakiety i przeciwrakiety w Zatoce Perskiej, „Wojskowy Przegląd Zagraniczny” Warszawa 1991, nr 1, s. 119-121; I. Witkowski, Taktyczny system obrony powietrznej „Patriot”, „Technika Wojskowa” 1991, nr 1, s. 17-18.

49 W. Gontarski, Dlaczego przegrywa Husajn?, „Rzeczpospolita” z 1 III 1991, nr 51, s. 9. Vide też J. Grzegorzewski, Patriot i $S-300$. Rakietowe systemy przeciwlotnicze, „Przegląd Wojsk Lotniczych i Obrony Powietrznej” Warszawa 1991, nr 12, s. 52-54.

50 M. Miarka, War with Iraq In View of internatinal Law. Views and Documents, Zeszyty Akademii Dyplomatycznej, Warszawa 2003, z. 2, s. 19, 47-48.

51 Zatoka Perska. Czy wszyscy powiedzq „tak”?, „Trybuna” z 30 XI 1990, nr 244, s. 1.

52 M. Flemming, Ultimatum w prawie międzynarodowym, „Polska Zbrojna” z 3 I 1991, nr 2, s. 3; Rezolucje Rady Bezpieczeństwa w sprawie Iraku, „Rzeczpospolita” z 1 III 1991, nr 51, s. 9; J. Menks, Konflikt iracko-kuwejcki w świetle prawa międzynarodowego, „Wojsko i Wychowanie” Warszawa 1991, nr 7, s. 76-77.

53 ZSRR nie włączył swoich wojsk w skład sił koalicji. Państwo to zobowiązało się jednak przestrzegać rezolucji uchwalonych przez Radę Bezpieczeństwa ONZ. Agresję Iraku poparli przywódcy Libii, Jordanii i Organizacji Wyzwolenia Palestyny. 18 II 1991 r. prezydent ZSRR Michaił Gorbaczow wystąpił z pokojowym planem, który przewidywał wycofanie wojsk irackich z Kuwejtu. Stany Zjednoczone projekt ten odrzuciły. Vide P. Kłudka, Inwazja, „Wojsko i Wychowanie” Warszawa 1990, nr 12, s. 55; Bagdad pod bombami, „Życie Warszawy” z 5 II 1991, nr 30, s. 5; M. W., Broń 
było jednym z głównych dostawców broni do Iraku ${ }^{54}$. Według opinii Kremla kontrolę nad wprowadzeniem sankcji i wojskami koalicji sprawować powinno ONZ, nie zaś Stany Zjednoczone, dążące do przejęcia supremacji w rejonie Zatoki Perskiej. George Bush zdawał sobie sprawę z trudności powstrzymania Husajna, gdyby ten zajął terytorium Arabii Saudyjskiej. Stąd też 8 sierpnia prezydent USA zapowiedział wysłanie na Środkowy Wschód wojsk amerykańskich ${ }^{55}$.

Po zajęciu Kuwejtu wiele wskazywało na to, że kolejną ofiarą agresji Iraku może być Arabia Saudyjska ${ }^{56}$. Wkrótce państwo to zwróciło się do Rady Bezpieczeństwa ONZ, aby zagwarantowała bezpieczeństwo jego granic. Trwającą od sierpnia do grudnia 1990 r. operację ochrony Arabii Saudyjskiej opatrzono kryptonimem „Pustynna Tarcza” („Desert Shield”). W tym czasie pod przewodnictwem Stanów Zjednoczonych sformowała się koalicja. W jej skład weszły: Wielka Brytania, Francja, Egipt, Syria, Pakistan, Katar, Włochy, Polska, Czechosłowacja, Maroko, Nigeria, Bahrajn, Oman, Zjednoczone Emiraty Arabskie ${ }^{57}$, Bangladesz, Senegal i Afganistan ${ }^{58}$.

Dowództwo nad operacją wyzwolenia Kuwejtu, 10 sierpnia prezydent George Bush powierzył dowódcy Amerykańskich Sił Szybkiego Reagowania (CENT$\mathrm{COM})$ gen. por. Normanowi Schwarzkopfowi. W czasie operacji podlegali mu dowódca Sił Lądowych (ARCENT) gen. Yeosock, dowódca Sił Powietrznych (CENTAF) gen. Charles Horner ${ }^{59}$, dowódca Sił Morskich (NAVCENT) i jednocześnie

dla Iraku, „Rzeczpospolita” z 7 II 1991, nr 23, s. 8; T. Barzdo, Pokojowy plan, „Życie Warszawy” z 19 II 1991, nr 42, s. 1, 5; T. Wróblewski, O propozycji radzieckiej w USA, „Życie Warszawy” z 19 II 1991, nr 42, s. 5; Błyskawiczna reakcja Bagdadu na pokojowy plan Gorbaczowa, „Życie Warszawy” z 20 II 1991, nr 43, s. 1, 5; A. Klugman, Plan Gorbaczowa bumerangiem, „Rzeczpospolita” z 20 II 1991, nr 43, s. 9; W. Gontarczyk, Koniec wojny?, „Rzeczpospolita” z 23-24 II 1991, nr 46, s. 1; T. Wróblewski, Ultimatum Busha, „Życie Warszawy” z 23-24 II 1991, nr 46, s. 1, 5; J. Kiwerska, Świat w latach 1989-2004. Wydarzenia - konflikty - procesy, Poznań 2005, s. 132-134. Vide też J. J. Kirkpatrick, Beyond the Cold War, Foreign Affairs, America and the World, New York, 1989/90, s. 1 i n.

54 W II 1972 r. Irak podpisał z ZSRR traktat o przyjaźni. D. Fedor, Irak na czarnej liście, „Gazeta Wyborcza” z 4-5 VIII 1990, nr 180, s. 1; Polska broń ptynie do Iraku?, „Gazeta Wyborcza” z 16 VIII 1990, nr 189, s. 1; P. Wieczorek, Kto dostarczat Irakowi broń?, „Wojsko i Wychowanie” Warszawa 1991, nr 5, s. 70-75.

55 A. Ł., Kalendarium konfliktu nad Zatokq Perska, ,Wojskowy Przegląd Zagraniczny” Warszawa 1991, nr 1, s. 95.

56 S. Tanner, op. cit., s. 84-85.

57 Irak grozi III wojna, „Gazeta Wyborcza” z 21 VIII 1990, nr 193, s. 1.

58 Łącznie koalicję stanowiło 38 państw. K. S., Kto pomagat uwolnić Kuwejt, „Trybuna” z 7 III 1991, nr 56, s. 5; K. Kubiak, Działania sit morskich po drugiej wojnie światowej. Studia przypadków, Warszawa 2007, s. 650-651; E. Cieślak, Dowodzenie lotnictwem w operacjach wielonarodowych, Zeszyty Naukowe Akademii Obrony Narodowej, Dodatek, Warszawa 2008, s. 60. Autor podał 36 państw.

59 J. Biziewski, op. cit., cz. 1, s. 21; R. Bielecki, op. cit., s. 80. Tu podano, że generał ten pełnił funkcje szefa sztabu Amerykańskich Sił Powietrznych. 
dowódca 7. Floty admirał Mautz, dowódca Piechoty Morskiej (MARCENT) gen. Boomer, dowódca Sił Specjalnego Przeznaczenia (SOCOM) gen. Johnson oraz dowódca Szkolenia Wojskowego w Arabii Saudyjskiej (USMTM) gen. Kaufman ${ }^{60}$.

W początkowym stadium „Pustynnej Tarczy” w rejon Arabii Saudyjskiej skierowano okręty wraz z lotniskowcami USS ${ }^{61}$ „Eisenhower” oraz USS „Independence”"2. Jesienią dołączyły do nich lotniskowce USS „Ranger”, USS „Midway” oraz okręty liniowe USS „Wisconsin” i USS „Missouri”. W działaniach przeciw Irakowi wzięły udział także USS „Saratoga”, USS „America” oraz krążownik USS „Princeton”. Jesienią w Zatoce Perskiej stacjonowało około 40 okrętów Sprzymierzonych, na Morzu Arabskim 30, na Morzu Czerwonym 25 i na Morzu Śródziemnym 13. Od sierpnia francuska grupa bojowa, której trzon stanowił lotniskowiec „Clemenceau”, kontrolowała wąską Cieśninę Ormuz ${ }^{63}$. Ponadto flota operująca w Zatoce Perskiej otrzymała zadanie prowadzenia ostrzału fortyfikacji i umocnień nabrzeżnych ${ }^{64}$. Fakt ten przyczynił się do związania na wybrzeżu kilku dywizji irackich. Na początku grudnia 1990 r. flota Sprzymierzonych liczyła 173 statki amerykańskie oraz 49 statków z innych państw.

Pod koniec pierwszej dekady sierpnia rozpoczęto przerzut myśliwców F-15C z USA do bazy wojskowej Dhahran na terytorium Arabii Saudyjskiej. Wkrótce do tej miejscowości dotarły F-117A (Black jet Stealth) ${ }^{65}$, F-15E Strike Eagle, F-16 Fighting Falcon, F-18 Hornet, brytyjskie Tornado GR1 oraz francuskie Mirage-2000, Mirage-F-1C oraz Jaguar GR-166. W gotowości do bombardowania irackich pozycji były bombowce B-52, które stacjonowały w Wielkiej Brytanii, Hiszpanii, Arabii Saudyjskiej oraz na wyspie Diego Garcia położonej na Oceanie Indyjskim ${ }^{67}$. Do przeprowadzenia operacji powietrznej przeznaczono około 1800 samolotów bojowych ${ }^{68}$. Od sierpnia do grudnia 1990 r. prowadzono rozpo-

60 Przebieg, analiza i ocena wojny w regionie Zatoki Perskiej, cz. I, „Wojskowy Przegląd Zagraniczny" Warszawa 1991, nr 4, s. 106; E. Cieślak, op. cit., s. 61 i n.

${ }^{61}$ USS - United States Ship - Okręt Stanów Zjednoczonych.

62 Wyja syreny, „Gazeta Wyborcza” z 3 X 1990, nr 230, s. 7.

${ }^{63}$ Nałożone przez Radę Bezpieczeństwa ONZ embargo spowodowało, że straty Iraku wynosiły około $30 \mathrm{mln}$. dolarów dziennie.

${ }^{64}$ Pociski jak samochody, „Gazeta Wyborcza” z 5 II 1991, nr 30, s. 1; K. Kubiak, op. cit., s. 654-718.

65 Wojna o Kuwejt. Koniec czy początek, „Gazeta Wyborcza” z 6 VIII 1990, nr 181, s. 1.

66 J. Gotowała, Lotnictwo we współczesnych konfliktach zbrojnych 1945-2003, Warszawa 2003, s. 174.

67 G. L. Hołdanowicz, Samoloty koalicji antyirackiej, cz. 2, „Żołnierz Polski” z 10 II 1991, nr 10, s. 4; J. Stefański, R. Maciejewski, Amerykańskie samoloty szturmowe, „Polska Zbrojna” z 25 II 1991, nr 39, s. 2; M. Paluszyński, Zatoka Perska. Lotnictwo i obrona powietrzna stron konfliktu, „Przegląd Wojsk Lotniczych i Obrony Powietrznej” Warszawa 1991, nr 10, s. 69-71.

68 G. L. Hołdanowicz, Samoloty koalicji antyirackiej, ,Żołnierz Polski” z 10 II 1991, nr 6, s. 4. 
znanie irackich obiektów. W tym celu korzystano z satelitów KH-11, Magnum, Vortex oraz Lacross ${ }^{69}$. Do zakłócenia pracy stacji radiolokacyjnych użyto samolotów: EF-111A Raven, F-4G Wild Weasel, EA-6B Prowler. Iracką łączność radiową zakłócały samoloty EC-130H Compas Call. Ponadto wykorzystano samoloty: TR-1 do kontrolowania ruchów wojsk naziemnych, RF-4C do nagrywania położenia wojsk irackich, RC-135 do rozpoznania elektronicznego, E-2C Hawkeye, E-8A z systemem JSTARS, oraz E-3A Sentry AWACS (Airborne Warning and Control System - system wczesnego ostrzegania) ${ }^{70}$. Warto dodać, że broń precyzyjna w operacji wyzwolenia Kuwejtu stanowiła 25-30\% całości środków użytych przez siły powietrzne ${ }^{71}$.

Od 10 sierpnia rozpoczął się przerzut oddziałów m.in. z Egiptu, Syrii, Maroka oraz Pakistanu. Jednocześnie przybyły oddziały amerykańskie: 82. Dywizja Powietrznodesantowa ${ }^{72}$, 101. Dywizja Powietrznoszturmowa, 11. Brygada Artylerii Przeciwlotniczej oraz 1. i 2. Zgrupowania Piechoty Morskiej ${ }^{73}$. W końcu sierpnia nadeszły pierwsze transporty czołgów M-1A1 Abrams oraz kilkaset bojowych wozów piechoty M-2 Bradley. Pod koniec grudnia rozpoczęto przerzut 1. Dywizji Zmechanizowanej ${ }^{74}$.

Podczas przerzutów wojsk, opracowano plan operacji wyparcia wojsk irackich z Kuwejtu. Wyzwolenia zmierzano dokonać w dwóch etapach. Pierwszy, pod kryptonimem „Pustynna Burza („Desert Storm”) 75 zakładał likwidację lotnictwa, obrony przeciwlotniczej, stanowisk dowodzenia, zgrupowań wojsk i ich

69 S. Grouard, Rola satelitów amerykańskich w regionie Zatoki Perskiej, „Wojskowy Przegląd Zagraniczny" Warszawa 1991, nr 1, s. 14-119.

70 M. Paluszyński, Zatoka Perska. Lotnictwo i obrona powietrzna stron konfliktu, „Przegląd Wojsk Lotniczych i Obrony Powietrznej” Warszawa 1991, nr 10, s. 71, 78; P. Preylowski, Wojna w Zatoce Perskiej jako pierwszy konflikt zbrojny ery wysoko rozwiniętych technologii, „Wojskowy Przegląd Zagraniczny" Warszawa 1992, nr 1, s. 92-101; J. Zimniewicz, Wojna powietrzna w rejonie Zatoki Perskiej, „Przegląd Wojsk Lotniczych i Obrony Powietrznej” Warszawa 1991, nr 5, s. 83-86; T. P. i M. R., Wykorzystanie systemów i środków radioelektronicznych w regionie Zatoki Perskiej, „Wojskowy Przegląd Zagraniczny” Warszawa 1992, nr 1, s. 118-127; S. Zajas, Wnioski i doświadczenia z użycia sit powietrznych w operacji „Iracka Wolnośc”. Odniesienia do operacji „Pustynna Burza” z 1991 roku, [w:] Operacja „Iracka Wolność”. Materiaty z konferencji naukowej zorganizowanej z inicjatywy i pod patronatem Ministra Obrony Narodowej, red. nauk. M. Krauze, Warszawa 2003, s. 172-174.

71 W operacji „Allied Force” w Kosowie (1999 r.) precyzyjne środki rażenia stanowiły ok. 90\%, zaś w „Endurance Peace” w Afganistanie (2001 r.) ich współczynnik wyniósł 40-50\%. Vide R. Olszewski, Organizacja i prowadzenie operacji powietrznej, sposób synchronizacji uderzeń z marynarka wojenna $i$ wojskami lądowymi. Przekazywanie informacji o skutkach uderzeń, [w:] Operacja „Iracka Wolność”..., s. 80.

72 J. Bullach, H. Morris, Wojna Saddama. Poczq̨ek konfliktu kuwejckiego i reakcja międzynarodowa, Poznań 191, s. 155-156.

73 „Newsweek” z 20 VIII 1990, nr 34, s. 12.

74 R. Maciejewski, Zatoka Perska. Wojna nerwów, „Polska Zbrojna” z 9 I 1991, nr 6, s. 1.

75 Nazwę tę rozciągnięto na całą operację wyzwolenia Kuwejtu. 
odwody, dróg, mostów oraz fabryk produkujących broń biologiczną i komponenty do wytworzenia głowic jądrowych. W drugiej fazie działań „Pustynny Miecz” (,Desert Saber") ${ }^{76}$, zaplanowano współdziałanie sił lądowych wspartych lotnictwem i marynarką wojenną. Operacja ta miała doprowadzić do odcięcia irackich wojsk rozmieszczonych w Kuwejcie i południowym Iraku od baz zaopatrzenia. Po tym fakcie zamierzano zniszczyć wojska irackie znajdujących się w Kuwejcie.

W dniu 15 stycznia 1991 r. siły Sprzymierzonych liczyły ponad 680000 żołnierzy ${ }^{77}$. Przed ich frontem znajdowało się około 550000 Irakijczyków uzbrojonych w 4200 czołgów, 2700 dział, 300 samolotów oraz 150 śmigłowców $^{78}$.

Operację „Pustynna Burza” rozpoczął 17 stycznia 1991 r. godz. 3.00 czasu miejscowego atak amerykańskich komandosów wspieranych przez śmigłowce szturmowe AH-64 Apache ${ }^{79}$. Celem ataku były przygraniczne radiostacje. Wkrótce m.in. nad Bagdad skierowano bombowce F-117A charakteryzu-

76 Kryptonim ten przejęto od planu działań VII. Korpusu Armijnego.

77 K. Nowak, op. cit., s. 7; W. Ślemp, Wojna o Kuwejt, „Myśl Wojskowa” Warszawa 1991, nr 4, s. 145. Tu siły koalicji (USA, Egipt, Wielka Brytania, Syria, Arabia Saudyjska, Francja) oceniono jako 490000 żołnierzy, 4368 czołgów, 1380 samolotów. 9 I 1991 r. do bazy King Khalid przyleciał 107 osobowy polski personel medyczny. Ponadto na wodach Zatoki Perskiej znalazły się ORP „Wodnik” i ORP „Piast”. Razem polski kontyngent liczył 319 osób. Wśród nich znalazł się m.in. ppłk Franciszek Gągor, późniejszy szef Sztabu Generalnego WP. W drodze do Zatoki Perskiej, „Polska Zbrojna” z 9 I 1991, nr 6, s. 1, 5; R. Malik, Królestwo islamu i ... wojny, „Rzeczpospolita” z 16 I 1991, nr 13, s. 8; E. Kolendo, W zasięgu „Pustynnej Burzy”, „Żołnierz Polski” z 17 II 1991, nr 7, s. 4; J. Rajch, Rodacy w koalicyjnej służbie, „Polska Zbrojna” z 9 I 1991, nr 6, s. 1-2; Z. Damski, Pod polska bandera w Zatoce Perskiej, ,Żołnierz Polski” z 21 IV 1991, nr 16, s. 16-17; R. Jasiński, Kuwejt: w morzu piachu, „Polska Zbrojna” z 9-11 VII 1993, nr 132, s. 4; B. Komorowski, Wyzwania Zatoki, „Polska Zbrojna” z 27 II 1998, nr 9, s. 9; K. Nalaskowski, Skierowanie polskiej jednostki wojskowej w rejon Zatoki Perskiej wypetnia konstytucyjna norme „użycia Sit Zbrojnych poza granicami Rzeczypospolitej Polskiej”, „Polska Zbrojna” z 27 II 1998, nr 9, s. 23; F. Gągor, K. Paszkowski, Międzynarodowe operacje pokojowe w doktrynie obronnej RP, Toruń 1999, s. 171; Z. Moszumański, Z. Palski, Wojsko Polskie w Iraku. Historia i wspótczesność, Warszawa 2003, s. 118-119; D. Kozerawski, Polskie kontyngenty wojskowe w operacjach pokojowych (1973-1999), „Przegląd Historyczno-Wojskowy” Warszawa 2005, nr 1, s. 97-98.

78 R. Maciejewski, ... a więc wojna?, „Polska Zbrojna” z 14 I 1991, nr 9, s. 1; R. Maciejewski, Rola środków masowego przekazu, „Żołnierz Polski” z 21 IV 1991, nr 16, s. 8; „Newsweek” z 13 VIII 1990, nr 33, s. 19.

79 Po trzydniowych debatach 12 stycznia 1991 r. Kongres Stanów Zjednoczonych zezwolił G. Bushowi na użycie wojsk przeciwko Irakowi. T. Wróblewski, Kongres USA wyrazit zgodę na użycie sity przeciwko Irakowi, „Życie Warszawy” z 13 I 1991, nr 11, s. 1, 5; A. Krajewski, Ameryka idzie na wojne, „Rzeczpospolita” z 16 I 1991, nr 13, s. 1, 7; A. Krajewski, Cztery, trzy, dwa, jeden..., „Rzeczpospolita” z 17 I 1991, nr 14, s. 1, 7; S. Grzymski, Ostatnie godziny, „Rzeczpospolita” z 17 I 1991, nr 14, s. 5; R. Malik, Wojna nad Zatokq Perska, „Rzeczpospolita” z 18 I 1991, nr 15, s. 1; A. Krajewski, Byle nie zapeszyć, „Rzeczpospolita” z 19-20 I 1991, nr 16, s. 5; Nocny egzamin. Przebieg działań wojennych komentuje płk dr Zbigniew Magnacki z Akademii Obrony Narodowej, „Rzeczpospolita” z 22 I 1991, nr 18, s. 1; G. L. Hołdanowicz, Jak walczy Apache, „Żołnierz Polski” z 21 IV 1991, nr 16, s. 7, 15; C. Szoszkiewicz, Amerykański śmigłowiec przeciwpancerny AH-64A „Apache”, „Technika Wojskowa” Warszawa 1991, nr 2, s. 14-19. 
jące się bardzo niskim współczynnikiem odbicia radarowego ${ }^{80}$. Każdy z nich przenosił po dwie bomby przeznaczone do burzenia konstrukcji betonowych. Jednocześnie Sprzymierzeni użyli pocisków samosterujących BGM-109C Tomahawk $^{81}$. Przenoszone przez bombowce strategiczne B-52 zostały wystrzelone z okrętów Amerykańskiej Marynarki Wojennej (US Navy) zakotwiczonych na Morzu Śródziemnym, Morzu Czarnym oraz w Zatoce Perskiej ${ }^{82}$. Wkrótce po rozpoczęciu działań zbrojnych nad Irakiem znalazły się brytyjskie samoloty Tornado GR1 uzbrojone w pociski Alarm, samoloty FA-18A z samonaprowadzającymi na radiostacje pociskami Harm, F-14 Tomcat oraz francuskie Mirage 2000 i Jaguary ${ }^{83}$. Z lotniskowców irackie cele bombardowały samoloty A-6E oraz A-6 $6^{84}$. W czasie nalotów bombowce B-52 zrzucały bomby kasetowe oraz bomby paliwowo-powietrzne BLU-82. Te ostatnie charakteryzowały się bardzo dużą siłą rażenia, porównywalną z bombą jądrową małej mocy ${ }^{85}$. Na przełomie stycznia i lutego pod ogień lotnictwa Sprzymierzonych dostały się dywizje Gwardii Republikańskiej ${ }^{86}$. Związki te były atakowane z częstotliwością 300 lotów dziennie. W ciągu pierwszych 14 dni ataku w wyniku działań lotnictwa koalicji, Irakijczycy stracili około 1700 czołgów, 925 transporterów opancerzonych oraz 1485 dział $^{87}$. Ponadto prawie w całości rozbito system radiolokacyjny oraz w 30\% łączność wojsk lądowych. „Pustynna Burza” wykazała efektywność lotnictwa Sprzymierzonych ${ }^{88}$. Wywarło ono duży wpływ na przebieg działań zbrojnych w Kuwejcie i przyczyniło się do załamania irańskiej obrony na lądzie.

80 R. Maciejewski, Zatoka Perska - widmo wojny, „Polska Zbrojna” z 4-6 I 1991, nr 3, s. 2; J. Stefański, R. Maciejewski, „Pustynna Burza” trwa, „Polska Zbrojna” z 22 I 1991, nr 15, s. 1, 5; L. Ciborowski, Nieuchwytny ptak, „Rzeczpospolita” z 1 II 1991, nr 26, s. 7; J. Grzegorzewski, Samolot myśliwski Lockheed F - 117A, „Wojskowy Przegląd Techniczny” Warszawa 1991, nr 6, s. 34-35.

81 Przebieg oraz doświadczenia i wnioski z wojny w rejonie Zatoki Perskiej, Warszawa 1991, s. 54.

82 J. Grzegorzewski, Pociski manewrujace Cruise, „Wojskowy Przegląd Techniczny” Warszawa 1991, nr 2, s. 31-32.

83 Ocena operacyjno-taktyczna $i$ wnioski $z$ wojny $w$ rejonie Zatoki Perskiej, Warszawa 1991, s. 61-67.

84 T. Wróblewski, Scenariusz na wypadek wojny. Pierwsze rakiety spadna na centrum dowodzenia w Bagdadzie, „Życie Warszawy” z 13 I 1991, nr 11, s. 5.

85 Amerykańskie bomby paliwowo-powietrzne, „Polska Zbrojna” z 20 II 1991, nr 36, s. 2; H. Hermann, Dziatania specjalne $w$ wojnach $i$ konfliktach zbrojnych po II wojnie świtowej, Warszawa 2000, s. 118.

86 J. Rajch, Husajn przegrupowuje sity, „Życie Warszawy” z 29 I 1991, nr 24, s. 1, 5.

87 Bagdad pod bombami, „Życie Warszawy” z 5 II 1991, nr 30, s. 5; K. Nowak, op. cit., s. 11.

88 F. Nietz, 2000 lotów bojowych, „Życie Warszawy” z 19-20 I 1991, nr 16, s. 1, 5; Pierwsze walki powietrzne, „Rzeczpospolita” z 26-27 I 1991, nr 22, s. $1,7$. 
Ostateczną klęskę wojskom irackim okupującym Kuwejt, zadały wojska lądowe zgrupowane w pięciu korpusach. Główne zadanie gen. Schwarzkopf powierzył przerzuconemu z Niemiec VII. Korpusowi Armijnemu ${ }^{89}$ osłanianemu od północy przez XVIII. Korpus Powietrznodesantowy. Te dwa związki taktyczne operujące w południowej części Iraku miały odciąć jego wojska okupujące Kuwej $^{90}$. Operacja „Pustynny Miecz” rozpoczęła się rano 24 lutego ${ }^{91}$. Siły koalicji biorące udział w tej największej od 1945 r. operacji wojsk lądowych, przedstawiały się następująco:

1) XVII. Korpus Powietrznodesantowy, w skład którego wchodziły:

a) amerykańska 82. Dywizja Powietrznodesantowa;

b) amerykańska 101. Dywizja Powietrznoszturmowa;

c) amerykańska 24. Dywizja Zmechanizowana;

d) francuska 6. Lekka Dywizja Pancerna;

Ponadto dowódcy tego korpusu podlegały oddziały amerykańskie: 7., 18., 212., 214. Brygady Artylerii Polowej, 12., 18. Brygady Śmigłowców Transportowych oraz 3. Rozpoznawczy Pułk Pancerny ${ }^{92}$.

89 Do bazy Dhahran siły główne tego korpusu przetransportowano w XI 1990 r. W wyniku opóźnień niektóre oddziały jeszcze w połowie I 1991 r. oczekiwały na swój sprzęt. Ćwiczenia „pustynnych szczurów”, „Rzeczpospolita” z 30 XI 1990, nr 279, s. 1, 5.

90 A. Krajowski, Ameryka jest dumna, „Rzeczpospolita” z 1 III 1991, nr 51, s. 7.

91 „Syndrom oszalatego psa”. Schwarzkopf o wojskach irackich, „Życie Warszawy” z 7 II 1991, nr 32, s. 1; Irak podpala szyby. Odliczanie przed ofensywa, „Życie Warszawy” z 8 II 1991, nr 33, s. 1, 5; Wojna nie schodzi „na ziemię”. Opóźnienie ofensywy lądowej, „Życie Warszawy” z 9-10 II 1991, nr 34, s. 1, 5; Bomby poprzedzaja ofensywę na lądzie, „Życie Warszawy” z 11 II 1991, nr 35, s. 5; W oczekiwaniu na ofensywę lądowa, ,Życie Warszawy” z 12 II 1991, nr 36, s. 5; A. Krajewski, Pytania o ofensywę laqdowq, „Rzeczpospolita” z 13 II 1991, nr 37, s. 9; S. Grzymski, Blizej kuwejckiej granicy, „Rzeczpospolita” z 14 II 1991, nr 38, s. 9; J. Klabiński, Irak dopuszcza możliwość wycofania się z Kuwejtu. Warunki nie do przyjęcia, „Gazeta Wyborcza” z $16-17$ II 1991, nr 40, s. 1, 5; Irak stawia warunki, „Życie Warszawy” z 16-17 II 1991, nr 40, s. 5; S. Grzymski, Saddam rozgrywa karte arabska, „Rzeczpospolita” z 18 II 1991, nr 41, s. 1, 11; J. Klabiński, Marines już sznuruja buty, „Gazeta Wyborcza” z 18 II 1991, nr 41, s. 5; Sprzymierzeni gotowi. Operacje ladowe - po rozmowach w Moskwie, ,Życie Warszawy” z 18 II 1991, nr 41, s. 1, 5; S. Grzymski, Znak, że wkrótce się zacznie, „Rzeczpospolita” z 19 II 1991, nr 42, s. 1, 7; Idem, Godzina ofensywy zależy od Husajna, „Rzeczpospolita” z 20 II 1991, nr 43, s. 1; Dyplomaci wstrzymuja ofensywę, „Życie Warszawy” z 21 II 1991, nr 44, s. 1, 5; S. Grzymski, Sadam Husajn ma jeszcze alternatywę. Kapitulacja lub klęska, „Rzeczpospolita” z 21 II 1991, nr 44, s. 1, 9; A. Krajewski, Wygrać pokój po wojnie, „Rzeczpospolita” z 22 II 1991, nr 45, s. 1, 9; T. Wróblewski, „Wojna najkrótsza droga do pokoju”, ,Życie Warszawy” z 22 II 1991, nr 45, s. 5; Decydujące uderzenie na Kuwejt, „Życie Warszawy” z 25 II 1991, nr 47, s. 1; K. G., Sadam Husajn nie wykorzystat ostatniej szansy. Ofensywa lądowa wojsk alianckich na Kuwejt, „Rzeczpospolita” z 25 II 1991, nr 47, s. 1; S. Grzymowski, Machina, którq trudno zatrzymać, „Rzeczpospolita” z 25 II 1991, nr 47, s. 11; A. Krajewski, Ultimatum Busha - siedem dni, „Rzeczpospolita” z 25 II 1991, nr 47, s. 11; T. Wróblewski, Wojnę zakończy odejście Husajna, „Życie Warszawy” z 25 II 1991, nr 47, s. 1, 5; A. Krajewski, Miażdżqcy poczq̨tek, „Rzeczpospolita” z 26 II 1991, nr 48, s. 1, 7. 92 http://www.tim-thompson.com [24 X 2009 r.]. 
2) VII. Korpus Armijny, w skład którego wchodziły:

a) amerykańska 1. Dywizja Pancerna, na wyposażeniu której było: 350 czołgów M1A1 Abrams, 330 bojowych wozów piechoty M-2 Bradley, 72 haubice M 109 oraz 8 wieloprowadnicowych wyrzutni rakietowych MLRS ${ }^{93}$;

b) amerykańska 3. Dywizja Pancerna (przydzielona z V. Korpusu Armijnego), która uzbrojona była w 350 czołgów M1A1 Abrams, 330 bojowych wozów piechoty M2/M3, 72 haubice M 109 oraz 8 wieloprowadnicowych wyrzutni rakietowych MLRS;

c) amerykańska 1. Dywizja Zmechanizowana, której podstawowym wyposażeniem było: 350 czołgów M1A1 Abrams, 280 bojowych wozów piechoty M-2 Bradley, 72 haubice M 109 oraz 8 wieloprowadnicowych wyrzutni rakietowych MLRS;

d) brytyjska 1. Dywizja Pancerna, licząca 28 tys. żołnierzy uzbrojonych w 157 czołgów Challenger MBT, 135 bojowych wozów piechoty Warrior IFV, 48 transporterów rozpoznawczych Scimitar, 88 samobieżnych haubic $155 \mathrm{~mm}$ M 109, 12 samobieżnych haubic 203,2 mm M 110, 12 wieloprowadnicowych wyrzutni rakietowych MLRS, 48 Samobieżnych Zestawów Przeciwlotniczych, 12 śmigłowców Gazelle oraz $24 \operatorname{Lynx}^{94}$

e) 2. Rozpoznawczy Pułk Pancerny, uzbrojony m.in. w: 125 czołgów M1A1 Abrams, 115 bojowych wozów piechoty M-2 Bradley, 24 haubice M 109 oraz 25 śmigłowców.

Ponadto dowódcy tego korpusu podlegały m.in.: 11. Brygada Śmigłowców, 42., 75., 142., 210. Brygady Artylerii Polowej, Brygada Inżynieryjna, 3. i 5. Grupy Sił Specjalnych, 160 Pułk Śmigłowców Sił Specjalnych";

3) Korpus „North” z kontyngentami takimi jak:

a) wojska egipskie:

- 3. Dywizja Zmechanizowana,

- 4. Dywizja Pancerna,

- Pułk Sił Specjalnych;

b) wojska syryjskie:

- 9. Dywizja Pancerna ${ }^{96}$,

- Pułk Komandosów;

93 J. Stefański, Artyleryjski zestaw MLRS, „Polska Zbrojna” z 21 I 1991, nr 37, s. 2; C. Szoszkiewicz, Armia amerykańska w wojnie o Kuwejt, „Technika Wojskowa” Warszawa 1991, nr 5, s. 10-11; I. Witkowski, MLRS. Podstawowy system artylerii rakietowej armii NATO, „Technika Wojskowa" Warszawa 1991/1992, nr 8, s. 8-11.

94 S. Orłowski, ,Miraże” $i$,fantomy” kontra fatamorgany, „Wiraże” z 3 II 1991, nr 3, s. 4.

95 http://www.vii-corps.org/DesertStorm/DesertStorm.htm [30 X 2009 r.].

96 R. Maciejewski, Zatoka Perska. Wojna nerwów, „Polska Zbrojna” z 9 I 1991, nr 6, s. 2. 
c) wojska saudyjskie:

- 20. Brygada Zmechanizowana,

- 4. Brygada Pancerna,

- Batalion Śmigłowców,

- Dywizjon Artylerii Polowej;

d) wojska kuwejckie:

- 35. Brygada Zmechanizowana,

- 15. Brygada Piechoty;

e) wojska nigeryjskie:

- Batalion Piechoty.

Siły te liczyły około 80000 żołnierzy operujących w czterech ugrupowaniach. Ich uzbrojenie stanowiło: 800 czołgów, 970 transporterów opancerzonych 510 dział oraz 21 śmigłowców uderzeniowych.

4) Korpus Piechoty Morskiej (USA), w tym:

a) 1. i 2. Dywizje Piechoty Morskiej;

b) Brygada Pancerna;

c) 2. Pułk Rozpoznawczy;

d) oddziały zabezpieczenia.

Ten liczący 53200 żołnierzy związek taktyczny, uzbrojony był w: 480 czołgów, 270 dział i wyrzutni rakietowych oraz 48 śmigłowców;

5) Korpus „East” z kontyngentami takimi jak:

a) Kuwejcka: Brygada Piechoty „Al Fatah”;

b) Marokański: 6. Pułk Zmechanizowany;

c) Omański: Batalion Piechoty Zmotoryzowanej;

d) Senegalski: Batalion Piechoty;

e) Katarski: Batalion Zmechanizowany;

f) Bangladeski: Batalion Piechoty;

g) Saudyjskie: 2., 8., 10. Brygady Zmechanizowane, Batalion Piechoty Morskiej;

h) Zjednoczone Emiraty Arabskie: Batalion Piechoty Zmotoryzowanej.

W dyspozycji dowódcy Korpusu „East” znajdowało się: 200 czołgów, 400 transporterów opancerzonych, 130 dział oraz 18 śmigłowców ${ }^{97}$.

$\mathrm{Na}$ lewym (północnym) skrzydle sił koalicji operował XVIII. Korpus Powietrznodesantowy. Głównym zadaniem tego związku taktycznego było wdarcie się w głąb Iraku i opanowanie szosy nr 8 położonej na $260 \mathrm{~km}$ od pozycji wyjściowych. Następnie miał skierować się na wschód i odciąć drogi odwrotu dywizjom Gwardii republikańskiej. Ponadto korpus ten miał osłaniać lewe skrzydło VII. Korpusu Armijnego. Atak poprzedziło rozpoznanie lotnicze oraz wypady wydzielonych pododdziałów na terytorium Iraku. W ich wyniku

97 http://www.tim-thompson.com [24 X 2009 r.]; J. Biziewski, op. cit., cz. 2, s. 9, 23, 34-37. 
zniszczono m.in. 15 bunkrów oraz wzięto do niewoli 476 jeńców. Rankiem (ok. 5.30) 24 lutego 1991 r. korpus uderzył trzema dywizjami. Na północnym skrzydle nacierała francuska 6. Lekka Dywizja Pancerna. Do jej głównych zadań należało zniszczenie irackiej 45. Dywizji Piechoty oraz opanowanie lotniska As-Salman. 25 lutego przy wsparciu śmigłowców Gazelle dywizja opanowała nakazane cele ${ }^{98}$. W następnym dniu operacji opanowano miejscowości położone na północ od As-Salman. W czasie działań wzięto do niewoli ponad 8000 jeńców oraz zdobyto m.in. 25 czołgów, 18 transporterów opancerzonych oraz 139 dział artylerii polowej.

W centrum ugrupowano amerykańską 101. Dywizję Powietrznoszturmową. Dywizja ta miała przeprowadzić atak z powietrza aż po Eufrat oraz od północy zablokować Basrę. W tym olbrzymim, jak na ówczesne czasy desancie helikopterowym, ważną rolę odegrały śmigłowce UH-60 Black Hawk oraz śmigłowce $30 \mathrm{CH}-47$. Do niszczenia irackich oddziałów pancernych użyto śmigłowców szturmowych AH-64 Apache uzbrojonych w pociski przeciwpancerne Hellfire ${ }^{99}$. Od początku operacji wspomagały je myśliwce F-16. Przy gwałtownych opadach deszczu 25 lutego dywizja opanowała odcinek drogi nr 8. Jej blokada ograniczyła dostawy zaopatrzenia oraz ograniczyła możliwości manewrowe wojsk irackich. Warto dodać, że oddziały irackie nie podjęły poważniejszej próby przedarcia się przez amerykańską blokadę.

Na prawym skrzydle korpusu operowała amerykańska 24. Dywizja Zmechanizowana ${ }^{100}$. Dywizja ta miała dojść do Eufratu, po czym wykonać zwrot na wschód. W jej pasie działania spodziewano się uporczywych walk oddziałami Gwardii Republikańskiej. W pierwszym dniu działań (24 luty) Amerykanie przełamali słaby opór 26. Dywizji Piechoty i wdarli się $80 \mathrm{~km}$ w głąb Iraku. 27 lutego dywizja znalazła się $120 \mathrm{~km}$ od Basry. Popołudniem tego dnia po ciężkich walkach stoczonych z 26., 49. Dywizjami Piechoty, Dywizją „Nabuchodonozor" oraz Brygadą Komandosów zdobyto lotniska Jalibah i Talil. Wieczorem w pobliżu Basry 24. Dywizja Zmechanizowana zaatakowała Dywizję „Hammurabi” ${ }^{101}$. Wobec silnego ognia artylerii rano 28 lutego Irakijczycy zmuszeni zostali do odwrotu ${ }^{102}$.

\footnotetext{
98 L. Lewina, Legia Cudzoziemska szybko zdobywa teren w Kuwejcie, „Życie Warszawy” z 25 II 1991, nr 47, s. 5.

99 M. Kopczewski, Zwalczanie śmigłowców bojowych przeciwnika w obronie, „Myśl Wojskowa” Warszawa 1993, nr 6, s. 104-105.

100 J. Biziewski, op. cit., cz. 2, Warszawa 1994, s. 16. Autor podał, że dywizja ta nacierała w centrum XVIII. Korpusu Powietrznodesantowego.

101 Nie przerwano ofensywy lądowej, „Życie Warszawy” z 27 II 1991, nr 49, s. 5.

102 Przebieg, analiza i ocena wojny $w$ regionie Zatoki Perskiej, cz. II, „Wojskowy Przegląd Zagraniczny" Warszawa 1992, nr 1, s. 111-113.
} 
Amerykańska 82. Dywizja Powietrznodesantowa stanowiła odwód dowódcy korpusu i w pierwszym dniu operacji przemieszczała się za dywizją francuską. Do działań zbrojnych weszła 25 lutego ${ }^{103}$. Wykorzystano ją jako jednostkę piechoty, przez co zaprzepaszczono walory mobilne tego związku taktycznego.

Drugim związkiem taktycznym koalicji, który uderzył na terytorium Iraku był VII. Korpus Armijny. W celu zajęcia pozycji wyjściowych od 17 stycznia do 18 lutego jego oddziały zostały przetransportowane znad granicy saudyjsko-kuwejckiej nad granicę saudyjsko-iracką. Korpus ten operował między prawym skrzydłem XVIII. Korpusu Powietrznodesantowego a granicą kuwejcko-iracką. W początkowej fazie ataku oddziały gen. Fredericka Franksa miały posuwać się na północ, a po rozbiciu pierwszorzutowych dywizji irackich skierować się na wschód ${ }^{104}$. Po wykonaniu tego manewru Basra znalazła się na lewym (północnym) skrzydle korpusu. W ten sposób obydwa korpusy odcinały drogi odwrotu wojskom irackim okupującym Kuwejt. W pierwszym rzucie na lewym skrzydle korpusu rozmieszczono 2. Rozpoznawczy Pułk Pancerny. Na prawo od niego rozwinęła się 1 . Dywizja Zmechanizowana, która operowała w centrum korpusu. Zadaniem ich było przedrzeć się przez czołowe irackie odziały na ich tyły i zniszczyć odwody ${ }^{105}$. Za 2. Rozpoznawczym Pułkiem Pancernym ześrodkowano 1. i 3. Dywizje Pancerne. Na południe od 1. Dywizji Zmechanizowanej rozmieszczono brytyjską 1. Dywizję Pancerną, która stanowiła odwód dowódcy korpusu $^{106}$. Na prawym skrzydle korpusu pozycje zajęła 1. Dywizja Kawalerii. Związek ten stanowił odwód gen. Schwarzkopfa.

Sukces lewoskrzydłowego XVIII. Korpusu Powietrznodesantowego oraz informacje o zamiarach wycofania się sił irackich, przyspieszyły atak VII. Korpusu Armijnego o 15 godzin. W dniu 23 lutego przekroczył wał graniczny i w odległości $15 \mathrm{~km}$ zajął pozycje obronne. Następnego dnia saperzy przygotowali przejścia $\mathrm{w}$ wale granicznym dla dywizji pancernych. Po półgodzinnym przygotowaniu artyleryjskim 24 lutego o godz. 15.00 siły główne korpusu ruszyły na północ. 2. Rozpoznawczy Pułk Pancerny nacierał 2. i 3. Batalionami Czołgów w pierwszej linii, które wspierał 4. Batalion Śmigłowców. W odwodzie posuwał się 1. Batalion Czołgów oraz artyleria. W pierwszym dniu działań pułk starł się z 26. Dywizją Piechoty. 25 lutego znalazł się ponad $50 \mathrm{~km} \mathrm{w}$ głębi Iraku, gdzie stoczył zwycięskie walki z Dywizją „Tawakalna”. Działania zbrojne pułk zakończył 26 lutego, rozbijając 50. Brygadę Pancerną z 12. Dywizji Pancernej. W nocy z 26 na 27 lutego przystąpił do zabezpieczenia wejścia do walki odwodowi korpuśnemu, 1. Dywizji Zmechanizowanej.

103 Z lądu $i$ z morza. Ofensywa Sprzymierzonych na Kuwejt i Irak, „Gazeta Wyborcza” z 25 II 1991, nr 47, s. 1.

104 „Newsweek” z 11 III 1991, nr 10, s. 22-23.

105 „Newsweek” z 25 II 1991, nr 8, s. 17.

106 Ibidem, s. 18. 
Drugim związkiem taktycznym przeznaczonym do przełamania irackich umocnień fortyfikacyjnych oraz pokonania pól minowych w pasie przygranicznym była 1. Dywizja Zmechanizowana. Dywizja atakowała 1. i 2. Brygadami Zmechanizowanymi w pierwszym rzucie. 3. Brygada Zmechanizowana stanowiła odwód. Oddziały te wspierał ogień trzech brygad artylerii z odwodu dowódcy korpusu. Rano 24 lutego dywizja weszła $10 \mathrm{~km}$ w głąb Iraku i przystąpiła do ostrzału artyleryjskiego pozycji obronnych nieprzyjaciela. Do wieczora wykonano przejścia w polach minowych oraz przygotowano wejścia dla brytyjskiej 1. Dywizji Pancernej. W drugim dniu operacji dywizja atakowała już trzema brygadami, przełamując obronę 28. Dywizji Piechoty ${ }^{107}$. W nocy z 25 na 26 lutego na jej odcinek weszła brytyjska 1. Dywizja Pancerna. Od rana 26 lutego 1. Dywizja Zmechanizowana, jako odwód dowódcy korpusu, przemieściła się nieco na północ i weszła na odcinek 2. Rozpoznawczego Pułku Pancernego. Rano 27 lutego przekroczyła jego front i uderzyła na 10. Dywizję Pancerną. Do końca dnia dotarła do drogi łączącej Kuwejt z Basrą.

Związkiem, który miał wspomóc uderzenie 1. Dywizji Zmechanizowanej była brytyjska 1. Dywizja Pancerna. Do walki weszła rano 25 lutego. Tego dnia toczyła pomyślnie walki z 48. i 31. Dywizjami Piechoty oraz 52. Dywizją Pancerną. Atakując 4. i 7. Brygadami Pancernymi w pierwszej linii 26 lutego, rozbito silne zgrupowanie irackie biorąc do niewoli ponad 7000 jeńców oraz przejęto m.in. 264 czołgi oraz 213 dział. W południe 27 lutego atak tej dywizji został wstrzymany.

Jak już wspomniałem, za lewym skrzydłem 2. Rozpoznawczego Pułku Pancernego skoncentrowano amerykańską 1. Dywizję Pancerną. Jej zadaniem było wejście na tyły nieprzyjaciela i zniszczenie odwodów. Po atakach z powietrza i ostrzale artyleryjskim pod koniec 24 lutego dywizja weszła $30 \mathrm{~km}$ na terytorium Iraku. W nocy z 25 na 26 lutego prowadzono ostrzał Al-Busayah, po czym rankiem miejscowość zdobyto. Po południu dywizja zmusiła do odwrotu na północ Dywizje „Adnan” i „Tawakalna” ${ }^{08} .27$ lutego w południe przed frontem dywizji znalazły się oddziały 2. Brygady Pancernej z Dywizji Pancernej „Medina”. W zwycięskim starciu Amerykanie zniszczyli 300 czołgów i wozów bojowych. Pod koniec dnia dywizja zaczęła ściągać swoje lewoskrzydłowe oddziały na południe. Było to spowodowane, faktem wprowadzenia na jej lewe skrzydło 1. Dywizji Kawalerii.

Na prawo od 1. Dywizji Pancernej operowała 3. Dywizja Pancerna z zadaniem rozbicia, zgrupowanych na tyłach wojsk irackich. W pierwszych dwóch dniach działań przeciwnik nie stawiał oporu. 26 lutego po południu przy wspar-

\footnotetext{
107 M. Skolarczyk, Brytyjskie dywizje na tyłach sił irackich, ,Życie Warszawy” z 25 II 1991, nr 47, s. 5.

108 Alianci na przedmieściach stolicy Kuwejtu, „Życie Warszawy” z 26 II 1991, nr 48, s. 5.
} 
ciu z powietrza i artylerii rozpoczęto atak na Dywizję Piechoty „Tawakalna”. Po jej rozbiciu, o świcie 27 lutego 3. Brygada Pancerna zaatakowała i pobiła 12. Dywizję Pancerną. Wieczorem 1. i 3. Brygady Pancerne zaatakowały wycofujące się oddziały irackie, dezorganizując ich odwrót. Od świtu do godz. 8.00 dnia następnego dywizja prowadziła ostrzał artyleryjski nieprzyjaciela.

Amerykańska 1. Dywizja Kawalerii działania zbrojne rozpoczęła 24 lutego, nacierając 2. Brygadą Pancerną wzdłuż Wadi al-Batin. Następnie przystąpiono do oczyszczania pól minowych i przygotowywania przejść przez wały graniczne. Atak tej dywizji miał zmylić dowództwo irackie, co do głównego kierunku ataku sił Sprzymierzonych. W drugim dniu operacji wycofano ją do odwodu dowódcy VII. Korpusu Armijnego. Do walki zamierzano ją wprowadzić 28 lutego na lewym skrzydle tego korpusu. Przerwanie ognia uniemożliwiło użycie tego związku taktycznego.

Do działań na terytorium Kuwejtu, Sprzymierzeni przeznaczyli trzy korpusy. Północnym (lewoskrzydłowym) związkiem taktycznym, mającym przekroczyć granicę saudyjsko-kuwejcką, był Korpus „North”. Korpus ten operował w najbardziej umocnionym odcinku frontu z zadaniem opanowania północno-zachodniej części stolicy Kuwejtu. W pierwszym rzucie uderzyły dywizje egipskie (lewe skrzydło korpusu) oraz oddziały saudyjski i kuwejckie (prawe skrzydło korpusu). Odwód stanowiła m.in. wojska syryjskie. W drugim dniu operacji Egipcjanie zdobyli lotnisko Ali As-Salim oddalone od Kuwejtu około 15 km ${ }^{109} .27$ lutego siły kuwejckiej 35. Brygady Zmechanizowanej weszły do stolicy Kuwejtu.

Na południe od Korpusu „North” nacierał Korpus Piechoty Morskiej. Jako pierwszy, rankiem 24 lutego granicę kuwejcką przekroczył 6. Pułk Piechoty Morskiej. Po wykonaniu przejść przez pola minowe, około południa do działań weszły siły główne 2. Dywizji Piechoty Morskiej, rozbijając 7. i 14. Dywizje Piechoty. Na zachodnie przedmieścia Kuwejtu dywizja dotarła 25 lutego, mając przed sobą 3. Dywizję Pancerną i 1. Dywizje Zmechanizowaną. Po długiej wymianie ognia Irakijczycy wycofali się. 26 lutego Amerykanie zajęli Al Jahrę i oczyścili okolice z oddziałów nieprzyjaciela. Od rana 24 lutego, także oddziały 1. Dywizji Piechoty Morskiej przygotowywały przejścia przez pola minowe. W pierwszym dniu ataku dywizja weszła $30 \mathrm{~km}$ w głąb Kuwejtu i obsadziła pole naftowe Al Burgan i część lotniska Al Jaber. Do zaciętych walk doszło 25 lutego z częścią oddziałów 5. Dywizja Zmechanizowanej. Do załamania irackiej obrony przyczynił się atak z powietrza, który wykonały samoloty FA-18, AV-8B oraz helikoptery Cobra. $\mathrm{W}$ nocy z 26 na 27 lutego opanowano międzynarodowe lotnisko na przedmieściach Kuwejtu, oczekując na nadejście Korpusu „East”.

Związkiem, który działał w pasie nadmorskim, był międzynarodowy Korpus „East”. Korzystając ze wsparcia ogniowego okrętów USS „Missouri” i USS „Wi-

109 Nie przerwano ofensywy lądowej, „Życie Warszawy”, nr 49 z 27 II 1991 r., s. 5. 
sconsin" w pierwszym dniu operacji, wszedł w głąb Kuwejtu. Przez kolejne dwa dni przeciwnik nie stawiał oporu. Do stolicy Kuwejtu oddziały korpusu weszły 27 lutego przed południem ${ }^{110}$.

Zawieszenie broni weszło w życie rano 28 lutego 1991 r. ${ }^{111}$ Główne cele Stanów Zjednoczonych zostały osiągnięte, tj. usunięto wojska irackie z Kuwejtu oraz przejęto kontrolę nad złożami ropy naftowej ${ }^{112}$. Wkrótce przeciwko Husajnowi wybuchły w Iraku powstania Kurdów na północy i szyitów na południu'113. G. Bush nie zdecydował się udzielić im pomocy w obaleniu Saddamowskiego reżimu. Prezydent USA potraktował je jako wewnętrzną sprawę Iraku ${ }^{114}$. Dyktator Iraku wówczas był potrzebny do zachowania równowagi sił w rejonie Zatoki Perskiej ${ }^{115}$.

Na początku marca $1991 \mathrm{r}$. Irak zaakceptował postanowienia rady Bezpieczeństwa ONZ ogłoszone w rezolucji nr 686 z 2 marca 1991 r. Były to:

- przewrócenie Kuwejtowi suwerenności i niezależności;

- wytyczenie granicy iracko-kuwejckiej zgodnie z porozumieniem z 4 października 1963 r.;

- wypłacenie Kuwejtowi odszkodowań;

- zakaz produkcji broni biologicznej i chemicznej ${ }^{116}$.

Prawie miesiąc później weszła w życie kolejna rezolucja nr 687. Zobowiązywała ona Husajna do zniszczenia broni masowej zagłady, systemu rakiet

110 Cały Kuwejt wolny, Nie przerwano ofensywy lądowej, „Życie Warszawy”, nr 50 z 28 II 1991 r., s. 5.

111 P. Salinger, E. Laurent, op. cit., s. 214. A. Klugman, Wojna skończy się, kiedy odejdzie Husajn, Rzeczpospolita, nr 53 z 4 III 1991 r., s. 7. Tu podano, iż prezydent Izraela stwierdził, że było to tylko przerwanie ognia, a nie zawieszenie broni; S. Grzymowski, Likwidacja ostatnich gniazd oporu irackiego. Kuwejt wolny, Rzeczpospolita, nr 51 z 1 III 1991 r., s. 1, 9; Pokój w Zatoce Perskiej, Życie Warszawy, nr 51 z 1 III 1991 r., s. 1, 5.

112 A. Towpik, Polityczno-militarne aspekty operacji „Iracka Wolność”, [w:] Operacja „Iracka Wolnośc”..., s. 15.

113 Wystapienia przeciw dyktatorowi, „Życie Warszawy” z 4 III 1991, nr 53, s. 5; Opozycja atakuje Husajna, „Życie Warszawy” z 5 III 1991, nr 54, s. 1, 5; R. M., Powstańcy z Basry proszq o pomoc, „Rzeczpospolita” z 5 III 1991, nr 54, s. 7; K. Szelestowska, Zamieszki w 12 irackich miastach. Odbicie Basry?, „Trybuna” z 7 III 1991, nr 56, s. 1; „Newsweek” z 25 III 1991, nr 12, s. 7-10.

114 A. Grgies, Sprawa kurdyjska w XX wieku, Warszawa 1997, s. 79-86; R. M., Husajn przebywa gdzieś w Iraku, „Rzeczpospolita” z 4 III 1991, nr 53, s. 1; T. Wróblewski, USA nie będzie sie narzucać, „Życie Warszawy” z 5 III 1991, nr 54, s. 5.

115 A. Krajewski, Dehusajnizacja Iraku, „Rzeczpospolita” z 27 II 1991, nr 49, s. 1, 9; A. Krajewski, Warunki końca wojny, „Rzeczpospolita” z 1 III 1991, nr 51, s. 9; W. Gontarski, Kto wygrat wojnę?, „Rzeczpospolita” z 2-3 III 1991, nr 52, s. 7; D. Warszawski, Dlaczego Husajn ocalat, „Rzeczpospolita” z 1 III 1991, nr 51, s. 7; R. Malik, Kto wygrat, kto przegrat?, „Rzeczpospolita” z 5 III 1991, nr 54, s. 7; G. Corm, Bliski Wschód w ogniu, Warszawa 2003, s. 333; W. Czarnecki, Cele strategiczne Iraku w operacji „Iracka Wolnośc” - próba rekonstrukcji, [w:] Operacja „Iracka Wolność”..., s. 22.

116 „Rzeczpospolita” z 5 III 1991, nr 54, s. 1, 7. 
balistycznych oraz wypłacenie Kuwejtowi reparacji wojennych. Międzynarodowa Agencja Energii Atomowej miała nadzorować zniszczenie środków niezbędnych do produkcji broni atomowej. W celu wycofania sił Sprzymierzonych do strefy zdemilitaryzowanej wprowadzono obserwatorów z UNKCOM (United Nations Iraq - Kuwait Observation Mission - Misja Obserwacyjna Narodów Zjednoczonych w Iraku i Kuwejcie) ${ }^{117}$. Ponadto utrzymano embargo na dostawy broni do Iraku ${ }^{118}$. Pomimo tych obostrzeń, polityka Husajna doprowadziła niemal 13 lat później do kolejnej interwencji koalicji noszącej kryptonim „Iracka Wolność”119.

\section{Coalition armies' activities in the region of the Persian Gulf in the years 1990-1991 (political and military aspects)}

In the article I concisely presented the historical background and the causes for the Iraqi aggression against Kuwait in 1990, triggering the first war in the Persian Gulf. The Iraqi invasion was immediately condemned by the United Nations Security Council, which issued a series of resolutions in which it persuaded Hussein to withdraw his troops from Kuwait. As a result of his disregard of the persuasion, the Allies, under the leadership of the USA, undertook an operation protecting Saudi Arabia (Operation Desert Shield). The next Allies' step was Operation Desert Sword. In its consequence Hussein's army was cut off from their supplies. In January 1991 the Allies started the next stage of their activities - Operation Desert Storm. It was then that the Allies' aviation broke the defence of the Iraqi land forces. On February 24, 1991 Operation Desert Sword began. It aimed at displacing Hussein from Kuwait and overtaking the control over oil deposits by the USA.

Despite the Allies' victory, Hussein was not defeated. His activities provoked another intervention of the coalition, leading to the operation called Iraqi Liberty or Gulf War II.

\footnotetext{
117 Cz. Marcinkowski, UNIKOM, „Wojska Lądowe” Warszawa 2003, nr 9, s. 24.

118 M. Miarka, op. cit., s. 17.

119 M. Bukowski, P. Ścigaj, Prasa codzienna wobec udziału polskich żotnierzy w operacji „Iracka Wolność”, [w:] Irak. Dylematy amerykańskiej interwencji, red. W. Dzielski, W. Michnik, Kraków 2007, s. 11-62; Z. Wojciechowski, Międzynarodowe konflikty zbrojne i wojny lokalne po II wojnie światowej, Zeszyty Naukowe Gdańskiej Wyższej Szkoły Administracji, Gdańsk 2007, z. 5, s. 373.
} 